vein grafting, revascularization with drug-eluting stents is quickly becoming the preferred treatment for these patients.

In the future, drug-eluting stents may be used for the prevention of acute coronary syndrome. It is believed that acute coronary syndrome is caused by unstable plaques of mild to moderate stenosis $(<50 \%)$ that do not result in angina symptoms. Given the high event-free survival rate achieved with drug-eluting stents, one could argue for treating these lesions with stent therapy and potentially changing their natural history. In addition, the effect of drug-eluting stents on other difficult lesion subsets, such as left main coronary artery disease, bifurcation disease and chronic total occlusions, is currently under investigation.

However, it is important to keep in mind that the efficacy of the drug-eluting stent is based on avoiding recurrent angina and ad- ditional revascularization procedures. These stents do not reduce the incidence of myocardial infarction or death. From an economic perspective, a recent analysis of the SIRIUS trial showed that, even though the use of drugeluting stents significantly increased the immediate procedural cost, there was no significant difference in cost at 1-year follow-up because of the reduced need for repeat revascularization.

Over the past 27 years percutaneous coronary intervention has undergone changes at a breathtaking pace. With the recent development of the drug-eluting stent, an even more spectacular evolution is taking place that will forever change the landscape of interventional cardiology.

\section{Yi-ming Yang}

Lenox Hill Hospital

Issam Moussa

Columbia University Medical Center Cardiovascular Research Foundation New York, NY

\section{References}

1. Mintz GS, Popma JJ, Pichard AD Kent KM, Satler LF, Wong SC, et al. Arterial remodeling after coronary angioplasty: a serial intravascular ultrasound study. Circulation 1996;94:35-43.

2. Hoffmann R, Mintz GS, Dussaillant GR, Popma JJ, Pichard AD, Satler LF, et al. Patterns and mechanisms of in-stent restenosis: a serial intravascular ultrasound study. Circulation 1996; 94:1247-54.

3. Moses JW, Leon MB, Popma JJ, Fitzgerald PJ, Holmes DR, O'Shaughnessy C, et al; SIRIUS Investigators. Sirolimus-eluting stents versus standard stents in patients with stenosis in a native coronary artery. $N$ Engl $7 \mathrm{Med}$ 2003;349(14):1315-23.

4. Moussa I, Leon MB, Baim DS, O'Neill WW, Popma JJ, Buchbinder $\mathrm{M}$, et al. Impact of sirolimus-eluting stents on outcome in diabetic patients: a SIRIUS (SIRolImUS-coated Bx Velocity balloon-expandable stent in the treatment of patients with de novo coronary artery lesions) substudy. Circulation 2004;109:2273-8.

5. Stone GW, Ellis SG, Cox DA, Hermiller J, O'Shaughnessy C, Mann JT, et al; TAXUS-IV Investigators. A polymer-based, paclitaxel-eluting stent in patients with coronary artery disease. N Engl 7 Med 2004;350(3): 221-31

\title{
SCience ANd Medicine
}

\section{Do stem cells cause gastric cancer?}

A lthough the link between Helicobacter pylori infection and gastric cancer is well established, new research suggests that stem cells play an important role in the development of this malignant disease. JeanMarie Houghton and colleagues recently showed that $H$. pylori-induced inflammation in mice caused the migration of stem cells originating from bone marrow to the stomach, where they subsequently developed into gastric tumours. ${ }^{1}$ Previous evidence suggests that bone-marrowderived cells have a reparative function on being recruited to areas of injury or inflammation. $\approx$ The idea that these cells might ठิ also play a role in the develop. ment of cancer revisits a concept 丞 that arose partly from the observation in the 1970 s that only $1 \%$ - of leukemia cells grow into colonies in vitro, an ability that Olater earned these cells the label "cancer stem cells." Houghton and colleagues' research suggests that similar stem cells may give rise to gastric cancer, a finding that presents a new way of think-

ing about the pathogenesis of a disease that is the second leading cause of cancer-related deaths worldwide, killing nearly 600000 people each year.

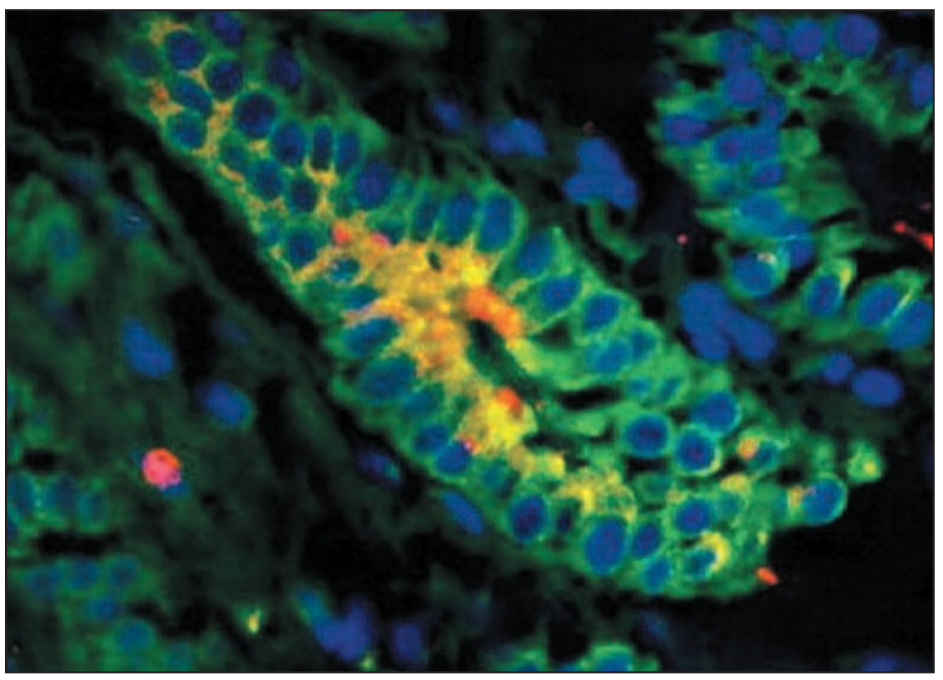

Bone-marrow-derived stem cell that has differentiated into a gastric epithelial cell. Reprinted, with permission, from Houghton et al. ${ }^{1}$ (C) 2004 American Association for the Advancement of Science. 


\section{H. pylori and cancer}

$H$. pylori is one of the most common chronic bacterial infections worldwide. The bacterium is the only one known to consistently tolerate the acidic environment of the stomach. Without treatment, $H$. pylori infection can persist for many years, causing chronic inflammation.

Up to $80 \%$ of patients with gastric cancer have a current or past $H$. pylori infection. ${ }^{3}$ This has led the World Health Organization to classify $H$. pylori as a group 1 carcinogen (www.cie .iarc.fr/monoeval/crthgr01.html). How the bacterium contributes to the development of cancer is still not entirely clear, although bacterial proteins, the immune response and hormonal responses have all been implicated. In addition, current research is beginning to link inflammation to the formation of tumours, with the inflammation-induced protein NF-kB emerging as a key factor. ${ }^{4}$

\section{Are stem cells to blame?}

Houghton and colleagues' work suggests an unexpected alternative to the inflammation theory. The research group focused on the idea that bone-marrowderived cells move into areas of chronic injury or inflammation to effect repairs. What longterm consequence this recruitment has on chronic inflammation is largely unknown. Houghton and colleagues wondered if these stem cells could be involved in the development of gastric cancer.

To study this question, Houghton and colleagues used a strain of mice (C57BL/6) and a relative of $H$. pylori (H. felis) that together form a well-established model of gastric cancer in humans. They irradiated the mice to destroy their natural bonemarrow-derived cells, replacing them with transgenic cells that would express easily detectable markers. Six to 8 weeks after the infection of these transgenic mice with $H$. felis, Houghton and colleagues began to detect bonemarrow-derived cells migrating into the stomach lining, presumably to repair the damage caused by the bacteria; by 20 weeks, the labelled cells were differentiating into cells with the characteristics of stomach epithelial cells.

But the authors found that these differentiating cells looked odd and behaved abnormally: they began to elongate, branch, crowd together and become distorted, and their growth rate started to accelerate. After 52 weeks, the mice were in the early stages of developing gastric cancer, and the tumours that subsequently formed stained positively for markers that indicated that the cells indeed came from the bone marrow.

Stem cells are often touted as holding great promise for novel therapies for problems ranging from myocardial infarction to Alzheimer's disease and parkinsonism. However, a recent revival of an old concept that stem cells may be the cellular origin of cancer is bringing a note of caution to the idea of using them to repair organs. (Cohnheim and Durante hypothesized 150 years ago that cancer might arise from embryonic stem cells, since the 2 types of tissue resemble each other. $\left.{ }^{5}\right)$ This revival got a jumpstart in 1997, when Bonnet and
Dick $^{6}$ from the University of Toronto made dilutions of leukemia cells to reveal that approximately one in a million had the ability to reproduce the disease, suggesting the presence of a "cancer stem cell." Similarly, Houghton and colleagues' work suggests that bone-marrowderived cells are cancer stem cells for gastric tumours.

However, this one study does not provide definitive proof, and more work is needed to show that the bone-marrow-derived cells in their model did indeed differentiate rather than merely fusing with epithelial cells. Furthermore, there is as yet no way to determine whether bonemarrow-derived cells cause gastric cancer in humans, since no markers are available. Nevertheless, these findings are a warning against the premature development of stem cell therapies and are bound to spark debate on the pathogenesis of gastric cancer. - David Secko, Vancouver

\section{References}

1. Houghton J, Stoicov C, Nomura S, Rogers AB, Carlson J, Li H, et al. Gastric cancer originating from bone marrow-derived cells. Science 2004;306: 1568-71.

2. Marx J. Bone marrow cells: The source of gastric cancer? Science 2004, 306:1455-6.

3. Peek RM, Blaser MJ. 2002. Helicobacter pylori and gastrointestinal tract adenocarcinomas. Nat Rev Cancer 2002;2:28-37.

4. Marx J. Inflammation and cancer: The link grows stronger. Science 2004;306: 966-8.

5. Behbod F, Rosen JM. Will cancer stem cells provide new therapeutic targets? [review]. Carcinogenesis Early online release 2004 Sept 30. Available: http://carcin.oupjournals.org/cgi /content/abstract/bgh293v1

6. Bonnet D, Dick JE. Human acute myeloid leukemia is organized as a hierarchy that originates from a primitive hematopoietic cell. Nature Med 1997;3(7):730-7. 